\title{
BIOEFFICIENCY OF BERMUDA GRASS, CYNODON DACTYLON (L.) ON THE FEEDING ACTIVITY OF SCHISTOCERCA GREGARIA (FORSK.) (ORTHOPTERA, ACRIDIDAE)
}

\author{
MOHAMED. T. MOHAMED
}

\author{
Plant Protection Res. Institute, ARC, Dokki, Giza
}

(Manuscript received 9 November 2008)

\begin{abstract}
The effects of Bermuda grass, Cynodon dactylone (L.) on approximate digestibility (AD), consumption index (CI), efficiency of conversion of ingested food (ECI) and digested food (ECD) into body substances as well as growth rate of the last nymphal instars of Schistocerca gregaria (Forsk.) were studied in the laboratory. The obtained results revealed that, feeding $4^{\text {th }}$ instar nymphs on the contaminated clover, Trifolium alexandrirum with leaves and roots extracts of burmuda grass in methanol, acetone and ethoxyethanol significantly reduced $A D, E C I$ and ECD. The reductions in these parameters were expressed as remarkable reduction in the body weight of the treated $4^{\text {th }}$ instar nymphs. The same treatments were conducted against the $5^{\text {th }}$ instar nymphs and resulted in significant increasing in $A D$ and $C I$, but ECI and ECD were decreased in comparison to the control. The decreasing in ECI and ECD was reflected as a reduction in the growth rate of the treated $5^{\text {th }}$ instar nymphs. It seems that, $5^{\text {th }}$ instar nymphs were more sensitive than $4^{\text {th }}$ one to the juvenilizing action of Bermuda grass because the increasing in $A D$ and $C I$ and the decreasing in ECI and ECD in the treated $5^{\text {th }}$ instar nymphs with the extracts of Bermuda grass are considered as a juvenilizing effect of this grass, which coinside with many other studies on plant extracts against insect pests. It is may refer to that Bermuda grass may include some effective compounds enable it to resist the desert locust plague.
\end{abstract}

\section{INTRODUCTION}

Recently, bioassaies of plant extracts against insects attracted much attention to develop environmentally acceptable alternative controlling methods against insects. Mordue (2004) supported the previous studies on this approach, when he stated that azadirachtin, the most effective isolated compound of the Neem tree, Azadirachta indica (Family, Meliaceae) exhibited strong antifeedant, repellent and growth regulator actions for a wide variety of phytophagous insects. In this direction, Jogar et al. (2006) found that, the treated pharate pupae of Tenebrio molitor with Ledum palustre plant extract transformed into extra-pupal instars, which is a symptom of its juvenilizing effect. El-gammal et al. (2008) obtained the same intermediate insects (adultoied) after feeding the $5^{\text {th }}$ instar nymphs of Schistocerca gregaria on treated 
clover with some plant extracts of Bermuda grass, Cynodon dactylon (L.). Also, Akhtar et al. (2008) stated that bioactivities of some plant extracts belonging to the family Maliaceae proved to be strong growth inhibitors and contact toxins.

Therefore, the present work aims to reveal the reasones of which the Bermuda grass, Cyonodon dactylon was argued to resist the infestations of the desert locust, Schistocerca gregaria in some area during the last plague 2004-2005 in Egypt.

\section{MATERIALS AND METHODS}

\section{A- Insects used}

Newly moulted $4^{\text {th }}$ and $5^{\text {th }}$ instar nymphs, Schistocerca gregaria (Forsk.) were segregated from gregarious colony of locust and grasshoppers Research Department and Kept in wooden - framed cages cube of $30 \mathrm{~cm}$ side under the crowded conditions as mentioned by Hunter-Jones (1961). These nymphs were fed on treated leaves of clover, Trifolium alexandrinum with some extracts from Bermuda grass, Cynodon dactylon. Unconsumed food, dead locusts and faeces were removed daily.

\section{B- Plant extracts preparation}

After one month of Bermuda grass, C. dactylon planting in experimental plots of clay soil, the grass was picked up, and allowed to dry in shadow under room temperature for 10 days. Air dried leaves and roots were separately grounded by house hold grinder. One hundred gram of each were soaked in $200 \mathrm{ml}$ of the solvents, methanol, acetone and ethoxyethanol for $48 \mathrm{hr}$, with continuous sterring. Filtration was conducted after soaking through fine gauze to get the supernatant of each extract for testing against $4^{\text {th }}$ and $5^{\text {th }}$ instar nymphs of $S$. gregaria.

\section{C- Treatments with plant extracts}

Populations of 45 and 30 nymphs of $4^{\text {th }}$ and $5^{\text {th }}$ instars were fed in 3 replications on treated leaves of clover with leaves and root extracts of Bermuda grass in methanol, acetone and ethoxyethanol for 6 days. The nymphs, were normally fed on untreated clover along the remained period to the next moult. The untreated $4^{\text {th }}$ and $5^{\text {th }}$ instar nymphs were daily fed on untreated leaves of clover.

\section{D- Criteria studied}

\section{Growth rate}

The treated and untreated nymphs were weighed daily to estimate their growth rate, according to the following equation of Waldbauer (1968): 


$$
\text { Mean }=\frac{\text { initial } \text { weight }+ \text { final weight }}{2}
$$

\section{Feeding activity}

Feeding activities of treated and untreated $4^{\text {th }}$ and $5^{\text {th }}$ instar were evaluated daily by measuring the faeces, food eaten and locust weights. The various indices of consumption and utilization of food were calculated on dry-weight basis according to the methods of Waldbauer (1968):

- Approximate digestibility (A.D.) $=\frac{\text { Food digested (D) }}{\text { Food ingested (F) }} \times 100$

- Consumption index $(\mathrm{C} . \mathrm{I})=\frac{\mathrm{F}}{\mathrm{TA}}$

$F=$ fresh or dry wt. of food ingested.

$\mathrm{T}=$ Duration of feeding period in days.

$A=$ Mean fresh or dry wt. of insect during feeding period.

- Efficiency of conversion of ingested food to body weight matter: (E.C.I.) = Dry weight gained

F- Dry wt.of faces $x 100$

- Wherease, Dry weight gained $=\frac{\text { Initial wt. }- \text { final wt. }}{2}$

\section{RESULTS AND DISCUSSION}

To realize the efficiency of Bermuda grass, Cyonodon dactylon, on food consumption, food utilization and growth of the last two nymphal instars of Schistocerca gregaria, newly moulted $4^{\text {th }}$ and $5^{\text {th }}$ instar nymphs allowed to feed on treated leaves of clover with different extracts from this grass for 6 days. These extracts were in methanol, acetone and ethoxyethanol. Food consumption, food utilization and growth rates of the treated nymphs were estimated as, approximate digestibility (A.D.), consumption index (C.I), efficiency of conversion of ingested food to body substances (ECI) and efficiency of conversion of digested food to body substances (ECD) according to Waldbauer (1968). The obtained results were :

\section{Effects of Bermuda grass on feeding activity of $4^{\text {th }}$ instar nymphs}

Table (1) shows that, the extracts of both leaves and roots of Bermuda grass in methanol and acetone significantly reduced A.D. of the treated $4^{\text {th }}$ instar nymphs in 
comparison to the untreated control. The percentages of A.D. were, 87.93, 88.64, and 88.35 after treatment with the extracts of leaves and roots in methanol and only roots in acetone, respectively compared with $91.22 \%$ in the untreated control. Consumptin index (CI) did not exhibit any differences than the control one. E.C.I values were strongly affected by these treatment, they were $13.59,9.87$ and $3.26 \%$ for each previous extracts, respectively compared with $24.47 \%$ in the control. E.C.D. also, was greatly declined by these extracts, its percentages were, 13.59, 11.29 and $10.38 \%$ after treatment with the same extracts, respectively compared with $26.75 \%$ in the untreated control.

These suppressions in conversion of the food ingested and food digested to body substances in the treated $4^{\text {th }}$ instar nymphs of $S$. gregaria resulted in reduction in the growth rate of these treated nymphs (Fig. 1). The growth rates were obviously affected by acetone roots extract followed by methanol roots extract and methanol leaves extracts.

\section{Effects of Bermuda grass on feeding activity of $5^{\text {th }}$ instar nymphs}

Table (2) indicates that, approximate digestibility (A.D) of the treated $5^{\text {th }}$ instar nymphs, S. gregaria was significantly increased compared with the untreated control. They ranged from $85.52 \%$ in the treated $5^{\text {th }}$ instar nymphs with the extract of Bermuda grass roots in acetone to $95.64 \%$ in the treated $5^{\text {th }}$ instar nymphs with roots extract in ethoxyethanol compared with $81.66 \%$ in the untreated control ones. The consumption index (C.I.) was also increased compared with the control. The values of C.I were ranged from 0.21 after feeding the $5^{\text {th }}$ instar nymphs on contaminated clover with the extract of Bermuda grass leaves in ethoxyethanol to 0.39 in the treated $5^{\text {th }}$ instar nymphs with its roots extract in methanol compared with 0.23 in the untreated control nymphs.

Also, Table (2) shows that, the conversion of ingested and digested food to body substances (E.C.I and E.C.D) was significantly decreased than untreated control $5^{\text {th }}$ instar nymphs. The percentages of E.C.I. ranged from 4.05 in the treated $5^{\text {th }}$ instar nymphs with the contaminated clover with the extract of Bermuda grass roots in acetone to $15.37 \%$ after treatment with its leaves extract in ethoxyethanol, compared with $22.63 \%$ in the untreated $5^{\text {th }}$ instar nymphs. Moreover, table 2 indicates that, the percentages of E.C.D. were also, decreased by treatment of the $5^{\text {th }}$ instar nymphs, $S$. gregaria with the tested extracts of Bermuda grass The maximum decreasing value was obtained after feeding the $5^{\text {th }}$ instar nymphs on the contaminated clover with acetone extract of Bermuda grass roots, it was $4.88 \%$, whereas the lower decrease was obtained after feeding on the contaminated clover with the extract of Bermuda 
leaves in ethoxyethanol (16.84\%), compared with $29.00 \%$ in the control nymphs. So, the deficiencies in the conversion of both ingested and digested food to body substances in the treated $5^{\text {th }}$ instar nymphs, S. gregaria with the indicated extracts of Bermuda grass (Table 2) were expressed in obvious decreases in their body weighs (Fig. 2).

In conclusion, all the plant extracts of Bermuda grass exhibited a strong reduction in feeding activity parameters of the treated $4^{\text {th }}$ and $5^{\text {th }}$ instar nymphs, $S$. gregaria, but the last instar was more sensitive than the other. These observations may be explained the resistance of Bermda grass to the infestations of the desert locust, S. gregaria during its last plague in Egypt, 2004-2005. The obtained decrease in the most effective parameters (ECI and ECD) of the treated nymphs on growth coincide with El-gammal et al. (2008) who stated that, the treated $5^{\text {th }}$ instar nymphs, S. gregaria were transformed into intermediate features of $5^{\text {th }}$ instar and adult stage after feeding on some selected extracts of Bermuda grass, C. dactylon. These symptoms are consider as a juvenilizing effects of this grass in $S$. gregaria. Thus, the inhibition effects of Bermuda grass extracts on $S$. gregaria feeding parameters, E.C.I and E.C.D as well as their growth rate may be attributed largly to some bioactive compounds in these extracts caused high level of juvenile hormone (JH) in the haemolymph of the treated last two nymphal instars of $S$. gregaria, specially the $5^{\text {th }}$ instar nymphs which were more sensitive than the $4^{\text {th }}$ one. Moreover, it was observed in the present study that, A.D. was higher in the treated $5^{\text {th }}$ instar nymphs, $S$. gregaria after feeding on tested extracts of the Bermuda grass, $C$. dactylon. All these findings could be explained by the results of Beenakkers et al. (1974) who stated that, the approximate digestibility (A.D) of the $5^{\text {th }}$ instar nymphs, Locusta migratoria was somewhat higher after implantation of corpora allata (the source of $\mathrm{JH}$ ) and lower after allatectomy, the ECI was greater in normally developing nymphs than in adults. Implantation lowered this efficiency of conversion in developing nymphs. Peter and Ananthakrishnan (1993) found that, azadirachtin-coated leaves had reduced body weight of Cyrtacanthacris tatarica (Orthoptera: Acrididae) and showed little variation in A.D, ECD and ECI compared with injected larvae. Also, Bhergava et al. (2005) studied the effects of plant products on food utilization of Carcyra caphalonica and observed that, $A D, E C I E C D$ were decreased and the weight gained by the larvae were reduced when fed on treated food with different plant extracts of, Pongamia glabra, Vitex negundo, Azadirachta indica, alophyllum inophyllum, Swietenia mahagoni and Brassica Juncea. More recent study was carried out by Nathan et al (2007) supported all the previous findings when they evaluated the toxicity and physiological effect of the botanical insecticide Dysoxylum triterpenes against the rice leaffolder 
Cnaphalocrocis medinalis. They found that, food consumption, digestion, relative consumption rate, ECI, ECD and relative growth rate values declined significantly but $A D$ of the treated larvae was significantly higher as a result of treatment.

Generally, the findings of the present study coincide with many other studies about the biological and physiological effects of plant extracts and botanical insecticides against insects which revealed that the Bermuda grass C. daclylon (L.) may includes many active principles for further study to isolate its active components in the future to prepare botanical insecticides for insect pests like $S$. gregaria.

Table 1. food consumption and food utilization by gregarious $4^{\text {th }}$ instar nymphs, Schistocerca gregaria as affected with some plant extracts from Bermuda grass, Cynodon dactylon L.

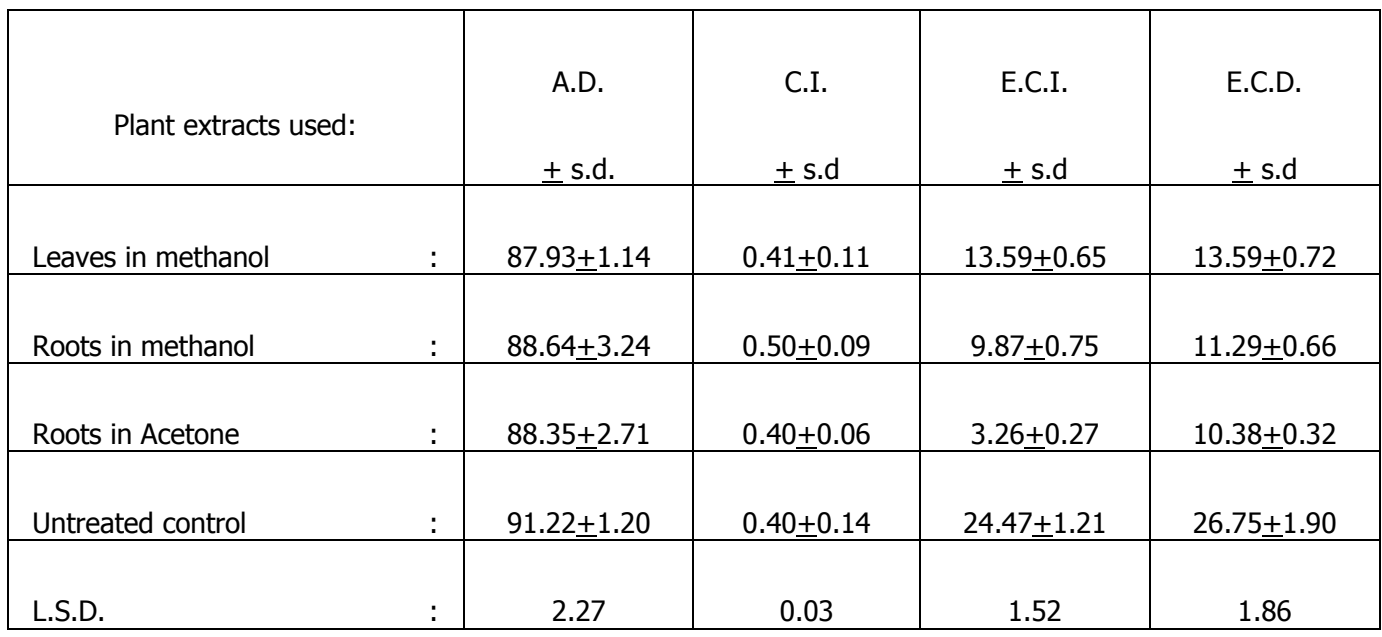

- Populations of 45 nymphs (males and females) were fed on treated leaves of clover, Trifolum alexandrinum with each indicated extracts.

- A.D. = Approximate digestibility, C.I = consumption index, E.C.I. = Efficiency of conversion of ingected food to body substances, and E.C.D. = efficiency of conversion of digested food to body substances. 
Table 2. effects of some plant extracts from Bermuda grass, Cynodon dactylon L. on food consumption and food utilization by $5^{\text {th }}$ instar nymphs, Schistocerca gregaria.

\begin{tabular}{|c|c|c|c|c|c|}
\hline Plant extracts used: & & $\begin{array}{l}\text { A.D. } \\
\pm \text { s.d. }\end{array}$ & $\begin{array}{l}\text { C.I. } \\
\pm \text { s.d } \\
\end{array}$ & $\begin{array}{l}\text { E.C.I. } \\
\pm \text { s.d } \\
\end{array}$ & $\begin{array}{l}\text { E.C.D. } \\
\pm \text { s.d }\end{array}$ \\
\hline Leaves in methanol & $:$ & $87.76+3.61$ & $0.37+0.04$ & $7.88+0.62$ & $9.88+0.68$ \\
\hline Roots in methanol & $:$ & $87.16+4.95$ & $0.39+0.03$ & $7.21+0.44$ & $8.08+0.49$ \\
\hline Leaves in Acetone & $:$ & $89.62+3.99$ & $0.27+0.03$ & $7.77+0.27$ & $8.89+0.99$ \\
\hline Roots in acetone & $:$ & $85.52+5.24$ & $0.28+0.08$ & $4.05+0.31$ & $4.88+0.40$ \\
\hline Leaves in ethoxyethanol & $:$ & $91.28+5.10$ & $0.21+0.04$ & $15.37+0.48$ & $16.84+0.52$ \\
\hline Roots in ethoxyethanol & $:$ & $95.64+4.53$ & $0.29+0.03$ & $5.41+0.13$ & $6.48+0.42$ \\
\hline Untreated control & : & $81.66+6.20$ & $0.23+0.03$ & $22.63+1.27$ & $29.00+1.88$ \\
\hline L.S.D. & $:$ & 4.03 & 0.04 & 1.38 & 2.01 \\
\hline
\end{tabular}

- Thirty nymphs (males and females) were fed on treated leaves of the Egyptian clover, Trifolum alexandrinum with each indicated extracts.

- A.D. = Approximate digestibility, C.I = consumption index, E.C.I. and E.C.D are the efficiency of conversion of injected and digested food to body substances.

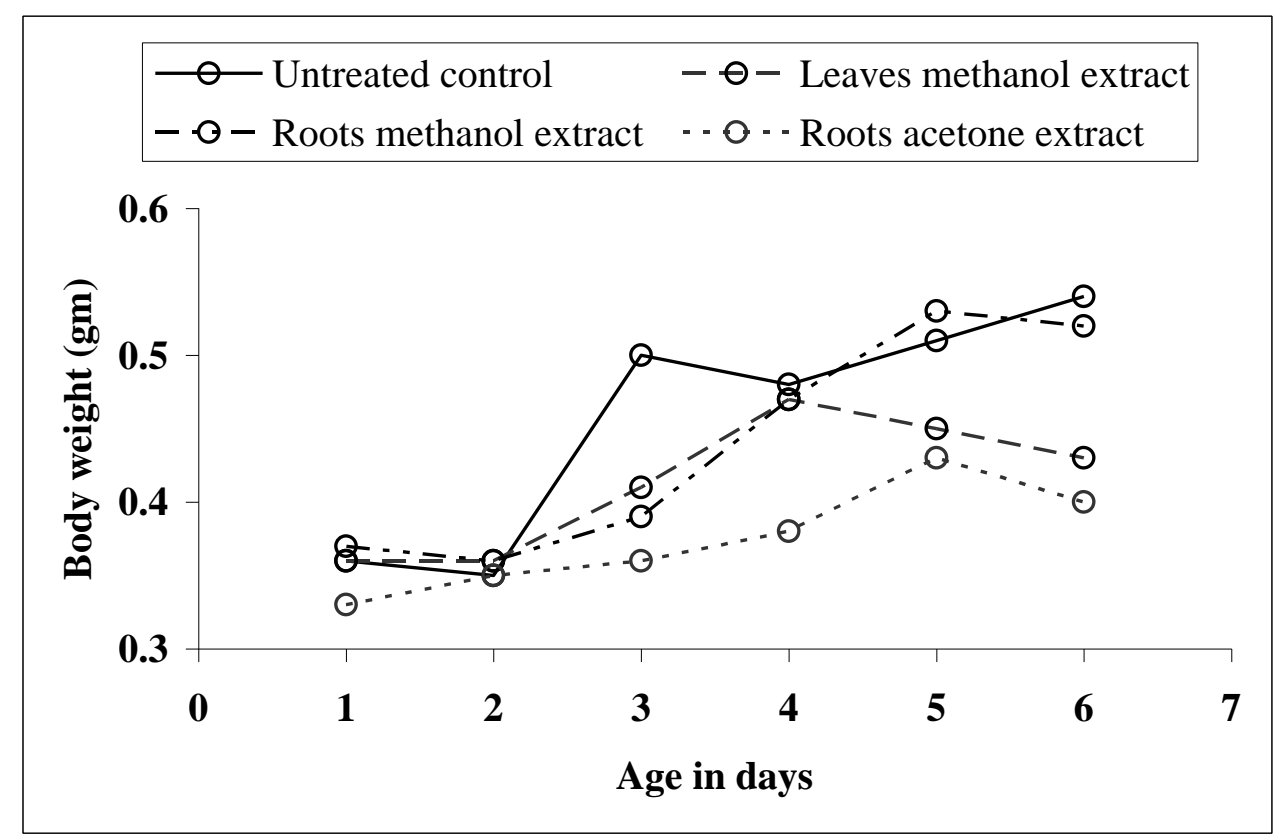

Fig. 1. Effects of different extracts from Bermuda grass, Cynodon dactylone on body weight of $4^{\text {th }}$ instar nymphs, Schistocerca gregaria (Forsk.) 

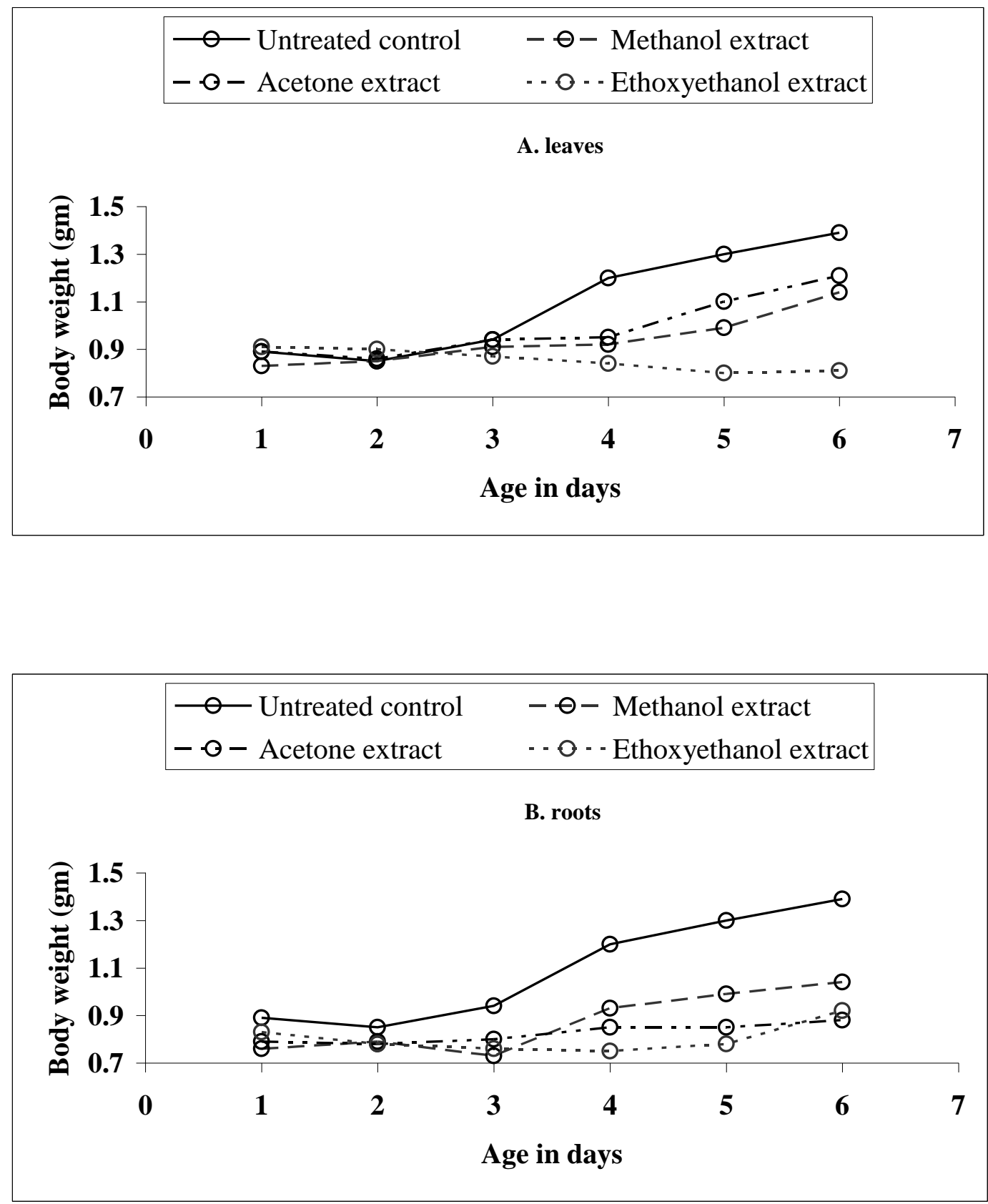

Fig. 2. Effects of different extracts from Bermuda grass, Cynodon dactylone on body weight of $5^{\text {th }}$ instar nymphs, Schistocerca gregaria (Forsk.) 


\section{REFERENCES}

1. Akhtar, Y., Y. R. Yeoung and M. B. Jsman. 2008. Comparative bioactivity of selected extracts from Meliaceae and some commercial botanical insecticides against two noctuid caterpillars, Trichoplusia ni and Pseudaletia unipuncta. Phytochemistry Reviews, 7: 77-88.

2. Beenakkers, A. M. T. and Broek, A. T. M. Van-den. 1974. Influence of Juvenile hormone on growth and digestion in fifth instar larvae and adults of Locusta nigratoria. J. Insect physiol. 20 (7): 1131-1142.

3. Bhergava, M. C., H. Akhtar and R. K. Choudhary. 2005. Effect of plant products on food utilization of Carcyra cephalonica station. J. Plant protection and behaviour. 2 (2): $72-74$.

4. El-gammal, A. M., Gihan A. M., M. T. Mohamed, H. A. Selim and N. Arif. 2008. Growth inhibitor effects of Bermuda grass, Cyonodon dactylon (L.) on Schistocerca gregaria (Forsk.) (Orthopter: Acrididae). Egyptian J. of Biological pest control. 18 (1): 81-85.

5. Hunter-Jones, P. 1961. Rearing and breeding locusts in the laboratory. Bull. Antilocusts Res. Center, London, 12.

6. Jogar, K., A. Kussik, L. Metspalu, K. Hiiesaar, A. Luik and Griskova. 2006. Results of treatments with natural insecticidal substances on the development and physiological state of insects. Agronomy Res. 4 (special issue), 203-210.

7. Mordue (Lundtz), A. J. 2004. Present consepts of the mode of action of Azadirachtin from neem. In Koul, O., Wahab, S. (eds): Neem: Today and in New Millennium. Kluwer Academic Publishers, London, pp. 229-243.

8. Nathan, S. S., Choi-Man Young, Paik - Chaehoon and Seo-Hongyul. 2007. Food consumption, utilization and detoxification enzyme activity of the rice leaffolder larvae after treatment with Dysoxylum triterpenes. Pesti. Bioch. and Physiol. 88 (3): 260-267.

9. Peter, A. J. and T. N. Ananthakrishnan. 1993. Effect of azadirachtin on the food utilization efficiency and digestive enzyme activity in Cyrtacantharis tatarica (Orthoptera: Acrididae). Phytophaga. 5(1): 35-43.

10. Waldbauer, G. 1968. The consumption and utilization of food by insects. Adv. Insect Physiol. 5: 229-288. 


\section{الكفاءة الحيوية لنجيل البرمودا (ساينودن داكتيلون) على استهلاك الغذاء فى الجراد الصحراوى "ثيستوسيركا جريجاريا (مستقيمات الأجنحة : جراديات)}

\section{محمد توفيق محمد}

$$
\text { معهر بحوث وقاية النباتات - مركز البحوث الزراعية - الدقى - جيزة . }
$$

تم دراسة تأثثر النجيل من النوع برمودا على معدل الهضم (AD) واستهلاك الغذاء (CI) وكفاءة

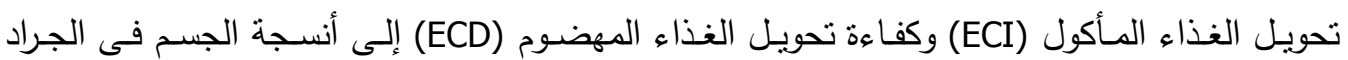
الصحراوى وكذللك أوزان الحوريات فى المعدل. أوضـت النتائج المتحصل عليها أن تغذيـة حوريات

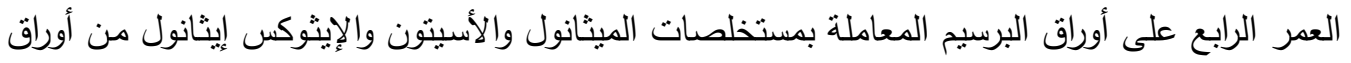

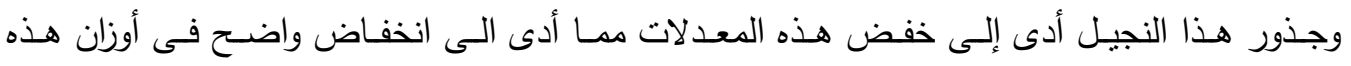

$$
\text { الحوريات. }
$$

كما أدت نفس المعاملات ضد حوريات العمر الخامس إلى زيادة معنويـة فى (CI, AD) ولكن

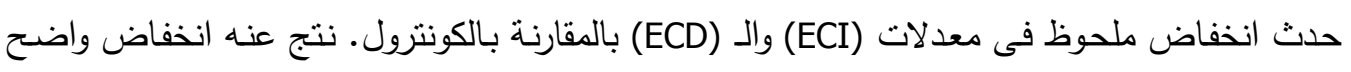

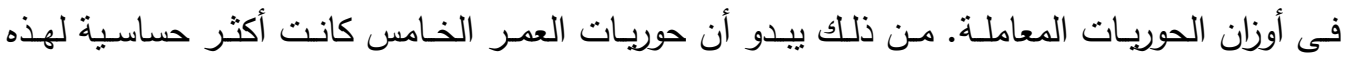

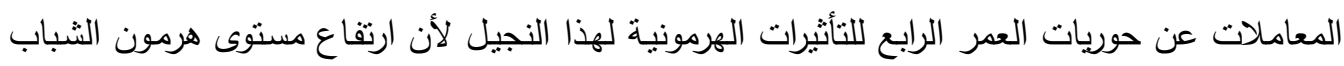
Juvenile hormone

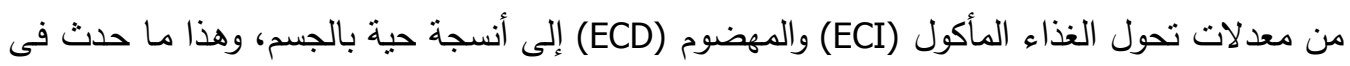

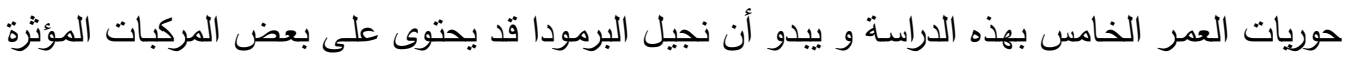
والتى ساعدته على مقاومة غزوات الجراد الصحراوى. 